\title{
Strategie rozwoju produktu w sferze kultury na przykładzie Polskiego Związku Kulturalno-Oświatowego w Republice Czeskiej
}

\begin{abstract}
Looking at the marketing strategies applied by institutions selling culture and education, the main problem is not to forget the nature of the selling product. We are obliged to protect the shape and essence of what we sell much more than selling any other kind of product even if the product is totally uncommercial. That's why numerous, cultural and educational institutions often aren't able to find their own place on the still changing market. Some of them offer products intended only for a small group of customers, others support new directions and new forms of products that haven't got their own type of clients definite yet. So there's appearing new need to reconciltae what's irreconcilable, extremly different opinions and need of working out the balance between spectators preferences and organizations ambitions. It looks like the developing product strategies of Polish Cultural and Educational Union in the Czech Republic presented in the paper prove that the balance is possible to reach.
\end{abstract}

\section{Keywords:}

culture marketing, strategic marketing, PZKO, product strategy, product development

${ }^{1}$ Łukasz Wróblewski, Katedra Zarządzania i Inżynierii Produkcji, Wyższa Szkoła Biznesu w Dąbrowie Górniczej Wydział Zamiejscowy w Cieszynie, Polska, lwoblewski@wsb.edu.pl. 


\section{WPROWADZENIE}

Działania strategiczne z zakresu marketingu w organizacjach takich jak Polski Związek Kulturalno-Oświatowy w Republice Czeskiej (PZKO) są już podejmowane, jednak ciągle w bardzo ograniczonym zakresie. Istota problemu wynika zarówno ze znaczenia tego typu organizacji w życiu lokalnych społeczności, braku wykwalifikowanej, stałej kadry, jak i z przydatności marketingu w rozwiązywaniu typowych trudności wynikających z ograniczeń systemu finansowania. Dodatkowo słabnący związek z polską kulturą (kulturą przodków) obywateli czeskich o polskich korzeniach (zwłaszcza młodego pokolenia) zamieszkujących na obszarze tzw. Zaolzia powoduje malejący popyt na świadczone przez PZKO usługi. Brakuje pieniędzy na utrzymanie obiektów (modernizację, czynsz, energię itp.), na inwestycje oraz rozwój oferty kulturalno-oświatowej. Przyczyny tego są różne; do podstawowych należą zmiany w gospodarce, które z jednej strony podwyższają koszty działania organizacji kulturalno-oświatowych, z drugiej zaś ograniczają dopływ środków finansowych z zewnątrz, tj. z budżetu państwa (czeskiego i polskiego) i budżetów terenowych. Organizacje taka jak PZKO muszą zatem kojarzyć swoją przyszłość z odmienną koncepcją działania, bliższą orientacji rynkowej aniżeli produktowej (Sobocińska, 2015; Noga, 2014; Ilczuk, 2012; Karna, 2008).

Niniejszy artykuł stanowi głos w dyskusji nad możliwością zastosowania typowych strategii produktowo-rynkowych przez podmioty kultury, w szczególności takie jak Polski Związek Kulturalno Oświatowy w Republice Czeskiej. Podstawy źródłowe prezentowanych rozważań stanowi literatura przedmiotu, dokumenty źródłowe PZKO oraz badania pierwotne autora - członka zespołu ds. strategii marketingowej PZKO - przeprowadzone w analizowanej organizacji na potrzeby prezentowanego opracowania.

\section{DZIAŁALNOŚĆ POLSKIEGO ZWIĄZKU KULTURALNO-OŚWIATOWEGO W REPUBLICE CZESKIEJ}

Polski Związek Kulturalno-Oświatowy w Republice Czeskiej (PZKO) jest stowarzyszeniem społecznym, które od 1947 roku działa na rzecz zachowania tożsamości rdzennej ludności Śląska Cieszyńskiego, pielęgnując rodzime tradycje, polską kulturę oraz szerząc oświatę w języku polskim. To największa organizacja w Europie zrzeszająca Polaków poza granicami Rzeczypospolitej Polskiej. Misją PZKO, która zapisana jest w Statucie Polskiego Związku Kulturalno-Oświatowego 
w Republice Czeskiej, jest zachowanie tożsamości narodowej Polaków żyjących na terenie Republiki Czeskiej, a w szczególności:

- ochrona i reprezentacja praw i interesów Polaków żyjących w Republice Czeskiej;

- zrzeszanie Polaków żyjących w Republice Czeskiej;

- wspieranie kultury i oświaty poprzez nawiązywanie do tradycji kultury polskiej, tradycji kultury Śląska Cieszyńskiego oraz uczestniczenie w wielokulturowym rozwoju Republiki Czeskiej i Europy;

- utrzymywanie powszechnego używania języka polskiego i promocji kultury polskiej w Republice Czeskiej;

- wspieranie polskich inicjatyw społecznych, kulturalnych i gospodarczych.

Do osiągnięcia misji PZKO dąży w szczególności poprzez:

- działalność edukacyjną, oświatę i organizację szkoleń;

- organizowanie i propagowanie wszelkiego rodzaju inicjatyw kulturalnych;

- prowadzenie działalności gospodarczej z przeznaczeniem dochodów na działalność statutową;

- promowanie i wspieranie inicjatyw i projektów w ramach PZKO;

- współpracę z organizacjami prywatnymi i publicznymi w kraju i za granicą;

- działania na rzecz integracji europejskiej oraz rozwijanie międzynarodowych kontaktów i współpracy;

- upowszechnianie oraz wspieranie kultury fizycznej, sportu oraz krajoznawstwa i wypoczynku;

- podejmowanie innych przedsięwzięć służących realizacji celów PZKO.

Działalność PZKO polega przede wszystkim na: organizowaniu polskiego życia społecznego według zainteresowań członków w zakresie śpiewu, muzyki i tańca, teatru amatorskiego, sportu, regionalnych inicjatyw samokształceniowych w zakresie historii regionu, ludoznawstwa, stosunków międzyludzkich, spraw socjalnych, a także zapewnienie organizacyjne, lokalowe i materialne tych czynności. Ważnym obszarem działalności organizacji jest również prezentacja wyników tych działań w postaci imprez miejscowych, obwodowych, regionalnych oraz międzynarodowych. Związek w 81 Miejscowych Kołach PZKO - od Bogumina do Mostów koło Jabłonkowa - skupia blisko 12000 członków regularnie opłacających składki członkowskie. Miejscowe Koła PZKO działają we wszystkich gminach Zaolzia i posiadają 45 „Domów PZKO”, które wykorzystują do realizacji własnych programów, a dorywczo i innych organizacji oraz do spotkań towarzyskich. Domy PZKO służące społeczności Zaolzia pełnią często funkcję jedynego domu kultury w miejscowości. W ich ramach działa 19 chórów z prawie 400 chórzystami, 8 teatrzyków, wśród nich dziecięce „Gapa 2” i „Drops”, oraz kapele ludowe: „Kamraci”, 
„Lipka”, „Nowina” i „Torka”. Rodzimą kulturę prezentują zespoły folklorystyczne, w tym również dziecięce - „Błędowice”, „Małe Błędowice”, „Bystrzyca”, „Łączka”, „Górole”, „Oldrzychowice”, „Młode Oldrzychowice”, „,Tyrka”, „Skotniczka”, „Śmiłowianie”, „Suszanie”, „Zaolzi”, „Zaolzioczek”, „Dziecka ze Stonawy” oraz Reprezentacyjny Zespół Pieśni i Tańca Zarządu Głównego PZKO „Olza”. Związek wydaje miesięcznik społeczno-kulturalny „Zwrot” oraz Kalendarz Śląski. Do zadań miesięcznika „Zwrot” należy: podejmowanie na swych łamach problematyki związkowej; promocja i propagacja działalności PZKO; komentowanie wydarzeń ważnych dla polskiej mniejszości w Republice Czeskiej.

\section{STRUKTURA PRODUKTU POLSKIEGO ZWIĄZKU KULTURALNO- -OŚWIATOWEGO W REPUBLICE CZESKIEJ}

W myśl teorii marketingu produktem jest wszystko, co stanowi przedmiot rynkowej wymiany. Produkt bywa też definiowany jako oferta czy propozycja sprzedaży weryfikowana przez rynek. Produktem może być przedmiot, usługa, miejsce, organizacja lub idea (Altkorn, 2004). Ponieważ większa część ofert w sektorze kultury, oświaty to świadczenie usług można przyjąć, że produktem Polskiego Związku Kulturalno-Oświatowego w Republice Czeskiej jest usługa polegają na:

- organizowaniu i propagowaniu ogólnozwiązkowych i regionalnych imprez, takich jak: „Gorolski Święto” (corocznie w Jabłonkowie), okolicznościowe „Festiwale PZKO” (w Trzyńcu i Karwinie), „Dzień Tradycji i Stroju Cieszyńskiego” - Cieszyn i Czeski Cieszyn, „Maj nad Olzą” w Darkowie, „Miyszanie owiec” (Koszarzyska), „Dzień Oszeldy w Nieborach”, „Uroczystość Wspomnieniowa Tragedii Żywocickiej 1944” (Obwód Hawierzowski), „Rocznica katastrofy lotniczej Żwirki i Wigury” w Cierlicku, „Dożynki Śląskie”, „Rajd do źródeł Olzy”, „Jesień z Kulturą” w Hawierzowie itp.;

- organizowaniu i prowadzeniu chórów, teatrzyków amatorskich, kapel ludowych, zespołów folklorystycznych, m.in. Reprezentacyjnego Zespołu Zarządu Głównego PZKO „Olza”;

- organizowaniu i prowadzeniu działalności oświatowej w postaci Uniwersytetu Dziecięcego prowadzonego wspólnie z Wyższą Szkołą Biznesu w Dąbrowie Górniczej czy Międzygeneracyjnego Uniwersytetu Regionalnego, organizowanie konferencji naukowych i popularno-naukowych, spotkań, prelekcji, wykładów, wystaw, konkursów np. gwary śląskiej itp.; 
- działalności wydawniczej (miesięcznik społeczno-kulturalny „Zwrot”, książki, albumy, kalendarze);

- wynajmowaniu sali wykładowej, samochodu, a także oferowaniu usługi ksero.

Usługa jest czynnością, akcją czy procesem, co oznacza, że jest ona konsumowana tak długo, jak długo trwa jej świadczenie, natomiast skutki tego świadczenia mogą być długofalowe (Styś, 1996). Usługi są niematerialne, nie można ich dotknąć, zobaczyć. Dotyczy to istoty samej usługi, a nie jej skutków, które mogą być materialne, jak np. skrypt do wykładu odbywającego się w ramach Międzygeneracyjnego Uniwersytetu Regionalnego PZKO. Wytwarzanie i konsumpcja przebiegają równocześnie. Oferty w dziedzinie kultury i oświaty są krańcowo heterogeniczne, tzn. niezwykle trudno jest porównać oferty nie tylko z różnych dziedzin, ale także w obrębie jednej. Jest oczywiste, że nawet te same koncerty folklorystyczne, wykonane przez ten sam zespół - np. Reprezentacyjny Zespół Zarządu Głównego PZKO „Olza” - w tym samym miejscu (np. w Teatrze im. Adama Mickiewicza w Cieszynie) różnią się. W odniesieniu do usług, produktu PZKO, możemy mówić o ich krańcowej nietrwałości. Nie można ich przechowywać ani gromadzić, większość z nich ma charakter „ulotny”. Trwały charakter mają jedynie „sprzedawalne” dzieła, np. wydawane skrypty MUR-u, książki, kalendarze czy rejestrowane na taśmach, płytach koncerty chórów, kapel, zespołów folklorystycznych. Owa trwałość zawsze jednak dotyczy nie samej usługi, ale jej efektu lub możliwości lepszego czy gorszego odtworzenia. Ostatnią cechą usług jest specyfika ich własności. Kategoria własności jest tu inna niż w przypadku fizycznych produktów. Odbiorca może uzyskać jedynie dostęp do usługi, do skorzystania z niej, nie może jej nabyć na własność.

Równocześnie należy pamiętać, że PZKO jest stowarzyszeniem społecznym zrzeszającym blisko 12000 członków, którzy regularnie opłacają składki członkowskie. Zgodnie ze Statutem PZKO, członkiem może być osoba fizyczna, która ukończyła 15. rok życia i z własnej woli podpisała deklarację członkowską, wyrażając tym samym zgodę na przestrzeganie Statutu PZKO, oraz wyraziła chęć współdziałania w jego przedsięwzięciach. Członek ma w szczególności prawo do: wybierania i bycia wybieranym do organów PZKO; zgłaszania opinii, wniosków i postulatów pod adresem tych organów i Miejscowego Koła PZKO; uczestniczenia w działalności związku i Miejscowego Koła PZKO. Członek zobowiązany jest do: dotrzymywania Statutu; przestrzegania regulaminów i uchwał organów PZKO i Miejscowego Koła PZKO; regularnego opłacania składek członkowskich (Statut PZKO). Można zatem przyjąć, że równie istotnym produktem PZKO (jak wymienione wyżej usługi) jest możliwość przynależności do związku, uczestnictwa w jego strukturach. 
Wiele współczesnych produktów (w tym produkty PZKO) jest tak naprawdę kompozycją elementów materialnych i niematerialnych, a warunkiem ich rynkowego sukcesu jest zdolność do zaspokojenia potrzeb nabywców. Stąd też w marketingu produkt postrzegany jest jako „wiązka korzyści” czy też „pakiet wartości” dla konkretnego nabywcy. Ten zaś przy zakupie kieruje się kilkoma ważnymi dla niego cechami produktu, które stanowią jego rdzeń, produkt oczekiwany oraz produkt poszerzony (rysunek 1).

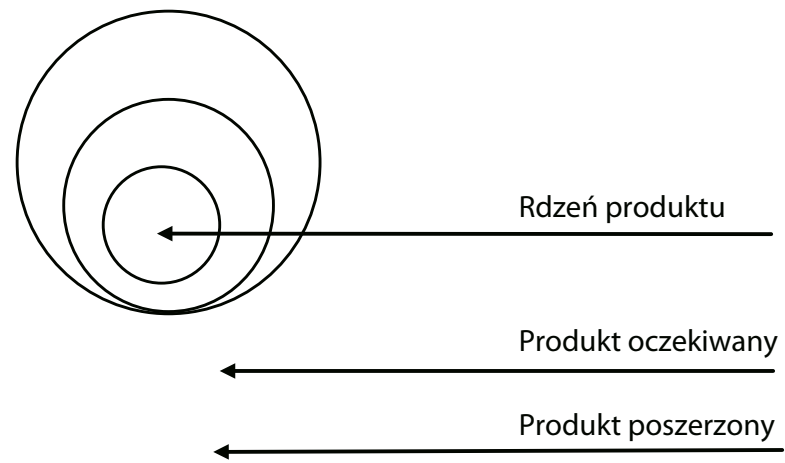

Rysunek 1. Struktura produktu organizacji kulturalno-oświatowej

Źródło: Kotler, Scheff, 1997, s. 192.

W przypadku członków PZKO sens rdzenia produktu można zrozumieć odpowiadając na pytanie, co dana osoba rzeczywiście kupuje, decydując się na wypełnienie deklaracji członkowskiej lub jaką podstawową potrzebę zamierza zaspokoić wstępując w szeregi Polskiego Związku Kulturalno-Oświatowego. Okazuje się, że rdzeń produktu, który oferowany jest przez PZKO w zależności od potrzeb członka, może przybrać różne formy. Dla jednych wstąpienie do PZKO jest formalnym potwierdzeniem ich polskiej narodowości, związku z kulturą kraju przodków. Inni upatrują w tym szansę na rozwijanie własnych zainteresowań, pasji czy też bardziej atrakcyjne i intensywne życie towarzyskie.

Z kolei produkt oczekiwany to zbiór cech i warunków, jakich oczekują klienci decydujący się kupić dany produkt. Członkowie PZKO mogą oczekiwać od związku możliwości uczestnictwa w wydarzeniach, imprezach organizowanych przez PZKO czy też np. możliwości czynnego uczestnictwa w zespołach organizacji (chórze, kapeli czy teatrzyku); podobnie jak w przypadku rdzenia produktu oczekiwania nabywców mogą być bardzo różne. 
Produkt poszerzony to produkt, który oferuje dodatkowe usługi lub korzyści, wyróżniające go od oferty konkurencji. Przykładowo osoby, które decydują się zasilić szeregi PZKO, mają możliwość nie tylko biernego uczestnictwa we wszystkich wydarzeniach organizowanych przez związek, ale również mogą włączyć się w ich organizację, mogą mieć realny wpływ na ich ostateczny kształt.

\section{STRATEGIE PRODUKTOWO-RYNKOWE}

Kiedy Polski Związek Kulturalno-Oświatowy w Republice Czeskiej określi poziomy produktu, może przejść do kształtowania strategii produktowo-rynkowych. Podstawowe znaczenie dla kształtowania tych strategii ma stopień zgodności cech i właściwości produktu z preferencjami nabywców. Wybór i zmiany kierunku działań w ramach strategii produktowo-rynkowych stanowią niezwykle istotną sferę decyzji strategicznych organizacji kulturalno-oświatowych. Podejmowane w ramach tych strategii działania mogą koncentrować się na:

- oferowanych produktach i zmianach ich właściwości,

- poszukiwaniach odpowiednich segmentów rynku,

- zmianach lub intensyfikacji innych działań i instrumentów marketingowych wspierających produkt w procesach pobudzania popytu (Wrzosek, 2004).

Podstawowymi zmiennymi w procesie kształtowania strategii produktowo-rynkowych są działania związane z produktem oraz zmiany rynków obsługiwanych nabywców. Cechy i właściwości oferowanego przez organizacje kulturalno-oświatowe produktu podlegają nieustannym konfrontacjom z potrzebami klientów. Jeżeli wynik tych konfrontacji jest pozytywny, to produkt zyskuje akceptację nabywców, a jego sprzedaż nie wymaga zmian w zakresie elementów kształtujących produkt. Jeśli zaś występują rozbieżności między wymaganiami nabywców dotyczącymi produktu a oferowanym produktem, to zachodzi konieczność wyboru i podejmowania działań mających na celu likwidację tych niedostosowań. Kształtowanie i wybór strategii produktowo-rynkowej jest reakcją organizacji kulturalno-oświatowej na zidentyfikowanie niedopasowania produkt-rynek, mającą umożliwić organizacji realizację jej celów. Relacje produkt-rynek opracowane zostały przez H.I. Ansoffa. Wyróżnił on cztery strategie działania przedsiębiorstwa, które z powodzeniem można stosować również w organizacjach kulturalno-oświatowych takich jak PZKO (rysunek 2):

Biorąc pod uwagę fakt, że misją Polskiego Związku Kulturalno-Oświatowego jest zachowanie tożsamości narodowej Polaków żyjących na terenie Republiki 

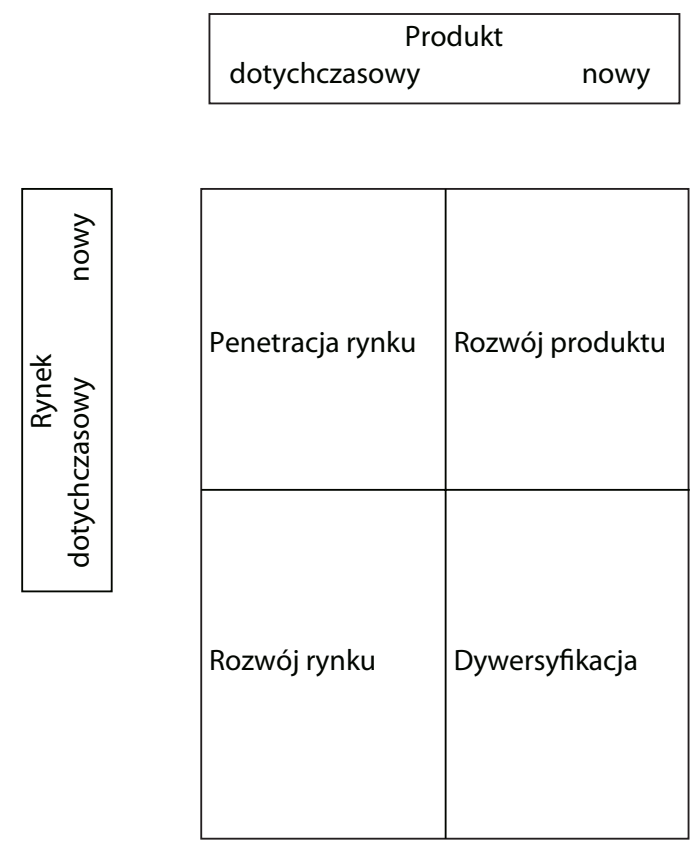

Rysunek 2. Strategie produktowo-rynkowe w ujęciu H.I. Ansoffa

Źródło: Ansoff, 1957, s. 114.

Czeskiej, propagowanie polskiej kultury głównie wśród społeczności Zaolzia (na obszarze, którego ta organizacja działa) wydaje się, iż najistotniejsze dla PZKO będą strategie rozwoju produktu na dotychczas obsługiwanym rynku. W niniejszym opracowaniu zaprezentowane zostaną najważniejsze strategie dotyczące rozwoju produktu PZKO.

\section{STRATEGIE ROZWOJU PRODUKTU}

Strategie rozwoju produktu opierają się na oferowaniu nowych lub zmodernizowanych produktów na dotychczasowym rynku. Podstawowym ich założeniem jest dostosowanie oferowanych produktów do wymagań rynku. Można wyróżnić następujące strategie rozwoju produktu: strategię doskonalenia produktu, strategię wydłużania linii produktu, strategię odmładzania linii produktu, strategię upraszczania produktu, strategię innowacji produktowych.

Strategia doskonalenia produktu może przybrać takie formy, jak: 
- podwyższenie poziomu jakości oferowanych produktów w przypadku PZKO. Jest to możliwe na przykład poprzez zwiększenie ilości prób zespołów artystycznych PZKO, odpowiednie wydłużenie czasu trwania tych prób, modernizacja sali koncertowej, wykładowej czy zakup nowego sprzętu nagłośnieniowego;

- podnoszenie stopnia wygody czy łatwości uczestnictwa w określonym wydarzeniu kulturalno-oświatowym: może to polegać na zapewnieniu transportu, sprawniejszej obsługi w szatni, zapewnieniu większej ilości miejsc parkingowych, bardziej wygodnych krzeseł w sali wykładowej czy lepszego nagłośnienia;

- poprawa bezpieczeństwa klienta w czasie organizowanego przedsięwzięcia z zakresu kultury bądź oświaty, np. poprzez czytelne oznakowanie wyjść ewakuacyjnych, zapewnienie odpowiednich środków przeciwpożarowych, punktów medycznych w czasie trwania plenerowych imprez kulturalnych, np. corocznego „Gorolskiego Święta” w Jabłonkowie;

- doskonalenie estetyki produktu organizacji - przykładowo zespoły folklorystyczne czy teatralne PZKO mogą zostać zaopatrzone w nowe stroje, kostiumy. Sala wykładowa, w której odbywają się wykłady Międzygeneracyjnego Uniwersytetu Regionalnego, może zostać gruntownie zmodernizowana i doposażona (nowe meble, sprzęt audio-wizualny) itp.

Strategia wydłużania linii produktu polega na wprowadzaniu na rynek nowych odmian dotychczas oferowanego produktu w celu zwiększenia lub utrzymania udziału w rynku. Strategia ta wykorzystywana jest z powodzeniem również przez Polski Związek Kulturalno-Oświatowy w Republice Czeskiej. Przykładowo, w 2005 roku na wniosek Rady Oświaty Zarządu Głównego przy PZKO powołano Międzygeneracyjny Uniwersytet Regionalny (MUR) z comiesięcznymi wykładami na poziomie uniwersyteckim. MUR nawiązuje do zamierzeń i sposobów działania „uniwersytetów trzeciego wieku”. W jego ramach raz w miesiącu organizowane są wykłady plenarne dla osób pełnoletnich - zazwyczaj emerytowanych członków PZKO. W 2014 roku podobne spotkania PZKO zaczęło organizować również dla dzieci ze szkół podstawowych. Zajęcia odbywały się w ramach uniwersytetu dziecięcego, którego zadaniem było popularyzowanie w języku polskim nauki wśród najmłodszych członków PZKO. Takie działanie w efekcie doprowadziło do wzrostu liczby oferowanych produktów - wydłużenia linii produktu PZKO.

Strategia odmładzania linii produktu jest stosowana w celu przywrócenia konkurencyjności starzejącym się produktom, postrzeganym przez nabywców jako nieodpowiadające ich wymaganiom. W ramach tej strategii PZKO podjęła próbę „odmłodzenia” prowadzonej działalności wydawniczej. Przykładowo redakcja 
miesięcznika społeczno-kulturalnego „Zwrot” obok tradycyjnego drukowanego magazynu postanowiła uruchomić również magazyn w wersji elektronicznej, w którym zamieszczane są m.in. aktualności z regionu, fotorelacje, ogłoszenia czy felietony. Z myślą o młodych czytelnikach redakcja „Zwrotu” podejmuje się również intensywnych działań w mediach społecznościowych - prowadzi swój fanpage na Facebooku, planowane jest wprowadzenie wirtualnych prezenterów oraz aplikacji mobilnych pobieranych na smartfony czy notebooki.

Strategia upraszczania produktu zakłada doskonalenie relacji między oferowanymi cechami i korzyściami z produktu a jego ceną. By poprawić te relacje przez obniżenie kosztów wytwarzania produktu, PZKO może stosować działania prowadzące do jego upraszczania. Polski Związek Kulturalno-Oświatowy w Republice Czeskiej jest organizacją społeczną, dlatego też bardzo często przy organizacji licznych wydarzeń kulturalnych pracują wolontariusze, którzy za swoją pracę nie otrzymują wynagrodzenia. Przykładowo przy organizacji konferencji naukowych, konkursów recytatorskich, przeglądów zespołów czy koncertów nie zatrudnia się zawodowych akustyków, oświetleniowców, tłumaczy, fotografów, bardzo często nie korzysta się z usług firm cateringowych - zadania te wykonywane są przez członków PZKO. Sprzęt, artykuły żywnościowe i inne materiały bardzo często udostępniane i przekazywane są bezpłatnie. Działacze PZKO bardzo chętnie podejmują się tego typu zadań, gdyż to stwarza im często możliwość własnego rozwoju, a dodatkowo umożliwia czynne uczestnictwo w wartościowych wydarzeniach, dlatego też nie oczekują na zapłatę. To z kolei prowadzi do uproszczenia produktu, a w rezultacie obniżenia jego ceny.

Strategia innowacji produktowych polega na podejmowaniu przez producenta celowych działań, których efektem jest oferowanie na dotychczas obsługiwanym rynku nowych produktów mających skutecznie pobudzić popyt i zapewnić realizację celów rozwojowych producenta (Wrzosek, 2004). Przykładem innowacji produktowych w sektorze kultury może być propozycja Polskiego Związku Kulturalno-Oświatowego w Republice Czeskiej polegająca na certyfikowaniu i znakowaniu marką „GÓROLSKO SWOBODA produkt regionalny®” produktów rolników, rzemieślników, małych i średnich firm z obszaru Regionu Śląska Cieszyńskiego. Marka ta została utworzona w ramach systemu marek regionalnych, który rozwija Stowarzyszenie Marek Regionalnych. Jest przyznawana produktom o charakterze konsumpcyjnym, użytkowym, produktom naturalnym i rolniczym, które spełniają kryteria certyfikacyjne. Przyznanie certyfikatu posiadania marki gwarantuje, że produkt jest: wykonany przez producenta z Mikroregionu Górolskiej Swobody (przygraniczny region na styku Czech, Polski i Słowacji, ograniczony Beskidem Śląskim, Morawsko Śląskim oraz Kisuckim, z pierwotną przyrodą, bogatymi trady- 
cjami i niepowtarzalnymi mieszkańcami), wysokiej jakości, oszczędny i przyjazny wobec środowiska naturalnego. Zdecydowana większość produktów wykonana jest z miejscowych surowców, tradycyjnymi technologiami rękodzielniczymi. Kupując markowy produkt, klient (turysta) ma możliwość nabycia oryginalnego i autentycznego upominku, pamiątki z Mikroregionu Górolskiej Swobody, wspierając dodatkowo konkretnego miejscowego producenta. Najczęściej spotykanym sposobem oznakowania produktów jest umieszczenie na produktach etykietek, naklejek czy przywieszek z logotypem. Markę przyznaje Jabłonkowskie Miejscowe Koło Polskiego Związku Kulturalno-Oświatowego w Republice Czeskiej produktom, które spełniają surowe kryteria (Wróblewski, 2016).

\section{ZAKOŃCZENIE}

Podsumowując można stwierdzić, że pomimo opinii licznych podmiotów sektora kultury, które nadal utożsamiają marketing, strategie marketingowe ze sprzedawaniem i uważają, że tego typu techniki obniżają wartość działalności, w którą się angażują, wiele nowoczesnych organizacji kulturalno-oświatowych już od dłuższego czasu posługuje się tymi strategiami, chociażby rozwijając swe produkty (Walotek-Ściańska, 2015; Varbanova, 2015; Wróblewski, 2016; Kurowska-Pysz, Wróblewski, 2015; Wróblewski, 2014). Przykładem takiej organizacji może być Polski Związek Kulturalno-Oświatowy w Republice Czeskiej. Oczywiście zbytnim uproszczeniem byłoby sądzić, że strategie produktowo-rynkowe zaproponowane głównie przedsiębiorstwom produkcyjnym przez H.I. Ansoffa, można „na ślepo” stosować w organizacjach kulturalno-oświatowych, bez jakichkolwiek modyfikacji. W sektorze kultury należy zachować bowiem równowagę między poglądami na kulturę obejmującymi twierdzenia, że ma ona sama w sobie immanentną wartość i należy ją chronić za wszelką cenę, a poglądami osób, które uważają, że podobnie jak każda inna forma działalności ludzkiej musi ona na siebie zarobić. Pojawia się więc potrzeba pogodzenia tych dwóch skrajnych opinii oraz wypracowania równowagi między preferencjami odbiorców oferty kulturalnej z jednej strony i potrzebami organizacji kulturalno-oświatowych z drugiej. Wydaje się, iż zaprezentowane w artykule strategie rozwoju produktu PZKO dowodzą, że taka równowaga możliwa jest do osiągnięcia. 


\section{Literatura:}

Altkorn, J. (2004). Marketing w turystyce. Warszawa: Polskie Wydawnictwo Naukowe. Ansoff, H.I. (1957). Strategies for Diversification. Boston: Harvard Business Review, t. 35. Ilczuk, D. (2012). Ekonomika kultury. Warszawa: Polskie Wydawnictwo Naukowe.

Karna, W.J. (2008). Zmiany w zarządzaniu publicznymi instytucjami kultury. Kraków: Wydawnictwo Uniwersytetu Jagiellońskiego.

Kotler, P., Scheff, J. (1997). Standing room only: strategies for marketing the performing arts. Boston: Harward Business School Press.

Kurowska-Pysz, J., Wróblewski, Ł. (red.), (2015). Wybrane problemy zarządzania i marketingu w instytucjach kultury. Dąbrowa Górnicza: Wydawnictwo Naukowe Wyższej Szkoły Biznesu w Dąbrowie Górniczej.

Noga, M. (2014). Kultura a ekonomia. Warszawa: Wydawnictwo CeDeWu.

Sobocińska, M. (2015). Uwarunkowania i perspektywy rozwoju orientacji rynkowej w podmiotach sfery kultury. Wrocław: Wydawnictwo Uniwersytetu Ekonomicznego we Wrocławiu.

Styś, A. (1996). Marketing usług. Wrocław: Wydawnictwo Akademii Ekonomicznej we Wrocławiu.

Varbanova, L. (2015). Zarządzanie strategiczne w kulturze. Warszawa: Narodowe Centrum Kultury.

Walotek-Ściańska, K. (2015). Teatry publiczne w województwie śląskim a social media. Katowice: Wydawnictwo Naukowe Śląsk.

Wróblewski, Ł. (2012). Strategie marketingowe w instytucjach kultury. Warszawa: Polskie Wydawnictwo Ekonomiczne.

Wróblewski, Ł. (red.), (2014). Zarządzanie w instytucjach kultury. Warszawa: Wydawnictwo CeDeWu.

Wróblewski, Ł. (2016). Marketing strategiczny w sektorze kultury Euroregionu Śląsk Cieszyński. Warszawa: Wydawnictwo CeDeWu.

Wrzosek, W. (2004). Strategie marketingowe. Warszawa: Polskie Wydawnictwo Ekonomiczne. 